\title{
FACTORS INVOLVED IN THE FERTILIZATION OF MOUSE EGGS IN VITRO
}

\author{
T. IWAMATSU* AND M. C. CHANG \\ Worcester Foundation for Experimental Biology, \\ Shrewsbury, Massachusetts 01545, U.S.A.
}

(Received 16th September 1970)

\begin{abstract}
Summary. Mouse eggs recovered from follicles before ovulation and from oviducts at various times after ovulation were inseminated in vitro with epididymal spermatozoa in the presence of heated bovine follicular fluid and examined $8 \mathrm{hr}$ after incubation. The eggs recovered $4 \mathrm{hr}$ before ovulation could be penetrated by spermatozoa and underwent fertilization, but their zona reaction to block further sperm entry was weaker than in eggs recovered $2 \mathrm{hr}$ before, or at various times after, ovulation. The failure of extrusion of polar bodies was observed in a high proportion of ovarian eggs undergoing fertilization. The fertile life of mouse eggs lasted about 10 to $12 \mathrm{hr}$ after ovulation and the failure of transformation of sperm heads as well as the activation of eggs was observed in the aged eggs. Sperm penetration and fertilization in vitro of tubal eggs could be influenced by spermatozoa or eggs from different strains of mice. The presence of epididymal extract appeared to inhibit sperm penetration. The concentration of spermatozoa, the concentration of calcium ions and the $\mathrm{pH}$ value of the medium during incubation could all affect the capacitation of mouse spermatozoa and the penetration of mouse eggs in vitro.
\end{abstract}

\section{INTRODUCTION}

Sperm penetration of mouse eggs could take place following the introduction of spermatozoa into excised oviducts (Brinster \& Biggers, 1965; Pavlok, 1967). Mouse eggs surrounded by cumulus oophorus and incubated with spermatozoa recovered from the uterus have been observed to undergo the first cleavage in vitro, as well as normal development in vivo after being transferred into the oviducts (Whittingham, 1968). It has been shown that, when mouse eggs were incubated with epididymal spermatozoa in the presence of heated bovine follicular fluid (Yanagimachi, 1969), capacitation of mouse spermatozoa in vitro and sperm penetration could be accomplished (Iwamatsu \& Chang, $1969,1970)$. The proportion of eggs penetrated under such conditions, however, varied a great deal in different preparations. Improvement of the experimental procedures and analysis of the factors affecting the percentage of eggs fertilized are of importance.

* Present address: Department of Biology, Aichi University of Education, Kariya-City, Aichi-ken, Japan (444). 
The present experiment was designed to determine the possibility of fertilization in vitro of mouse eggs obtained before, or at various times after, ovulation. The variations between different strains of mice, the effect of epididymal extract, sperm concentration, calcium concentration, and $\mathrm{pH}$ value on the fertilization of mouse eggs in vitro were also investigated.

\section{MATERIALS AND METHODS}

Eggs were obtained from mice at various times after injection of HCG (APL, Ayerst Lab.). Mature Swiss-Webster albino female mice (body wt 21 to $26 \mathrm{~g}$ ) were injected intraperitoneally with 5 i.u. $/ 0 \cdot 1 \mathrm{ml}$ of PMSG (Equinex, Ayerst Lab.), followed $48 \mathrm{hr}$ later by 5 i.u. $/ 0.1 \mathrm{ml}$ of HcG. In order to induce superovulation, the strain of C57BL/J6 mice (Jackson Lab.) and Swiss-Webster mice were injected intraperitoneally with 10 i.u. $/ 0.2 \mathrm{ml}$ of PMSG and HCG. Ovulation usually occurred between 11 and $13 \mathrm{hr}$ after the injection of HCG (Edwards \& Gates, 1959; McGaughey, Marston \& Chang, 1968).

The ovaries or oviducts were removed and the adhering blood was rubbed off on a piece of sterilized filter paper. The technique for recovery of eggs was the same as that described previously by Yanagimachi \& Chang (1964) for the golden hamster. The ovaries or oviducts were immediately put in the centre of a watch glass $(3.8 \mathrm{~cm}$ in diameter) containing 0.5 to $1.0 \mathrm{ml}$ of warm mineral oil (extra heavy, certified, Squibb Co.). Under a dissecting microscope, the walls of large follicles or the dilated ampullae of oviducts were cut with a glass needle and the eggs in the cumulus oophorus were released with a small volume of the surrounding fluid into the mineral oil. The empty oviducts, ovaries and other tissue débris were removed from the watch glass and the blood around the egg cumulus was drawn off with a fine glass pipette.

Spermatozoa were obtained from the epididymal tails and vasa deferentia of one or two mature males (body wt 28 to $32 \mathrm{~g}$ ). The epididymal tails and vasa deferentia were excised, immersed in $0.5 \mathrm{ml}$ of Tyrode's solution in a watch glass on a warm stage and cut with a pair of scissors. In a few minutes, masses of spermatozoa emerged and under a dissecting microscope, a cloudy portion of the suspension was taken into a fine glass pipette. The sperm suspension (about $0.03 \mathrm{ml}$ ) was dropped on to the egg clot and then heated bovine follicular fluid $(0.03 \mathrm{ml})$ was added. The mixture was incubated for $8 \mathrm{hr}$ and then the spermatozoa and eggs were examined under a phase-contrast microscope (Iwamatsu \& Chang, 1969, 1970).

The bovine follicular fluid was obtained by withdrawing the transparent, yellowish fluid from large follicles in cow ovaries collected from a local slaughter house. The fluid was stored in a sterile test tube at 0 to $10^{\circ} \mathrm{C}$. It was heated to $60^{\circ} \mathrm{C}$ for $10 \mathrm{~min}$ to remove a spermicidal factor (Yanagimachi, 1969).

For the study of the effect of epididymal secretion on fertilization in mice, ten epididymal tails in $1 \mathrm{ml}$ of Tyrode's solution were minced up and centrifuged at $3000 \mathrm{rev} / \mathrm{min}$ for $30 \mathrm{~min}$. The supernatant without spermatozoa was transferred to a sterile test tube and stored at 5 to $10^{\circ} \mathrm{C}$. It was warmed to $37^{\circ} \mathrm{C}$ just before use.

For the study of the effect of calcium during fertilization, Tyrode's solution 
with and without calcium was used. Calcium ions that might have been present in the bovine follicular fluid, the spermatozoa or the egg clot were not removed.

\section{RESULTS}

\section{Fertilization of ovarian eggs in vitro}

When forty-four ovarian eggs $(9 \mathrm{hr}$ after HCG injection and before the first meiotic division) were incubated with fresh epididymal spermatozoa for $8 \mathrm{hr}$, thirty-six eggs $(82 \%)$ had spermatozoa in the perivitelline spaces and thirty $(68 \%)$ were undergoing fertilization (at the stages of enlargement of sperm head or formation of pronuclei) (Table 1). All eggs undergoing fertilization had two or more large pronuclei, and also had two to fifty (mean 20.2) supplementary spermatozoa whose heads remained unchanged. Of the thirty eggs undergoing fertilization, twelve eggs $(40 \%)$ had one polar body and eighteen $(60 \%)$ had no polar body. Three to four pronuclei were found in five monospermic eggs; one trispermic and two dispermic eggs had no polar bodies.

Another group of eggs recovered from the follicles $9 \mathrm{hr}$ after the injection of HCG was treated with $0.1 \%$ of hyaluronidase for $5 \mathrm{~min}$ to disperse the attached follicular cells. When, after being washed with Tyrode's solution, the eggs were inseminated with epididymal spermatozoa, fifty-two $(63 \%)$ of eighty-two had spermatozoa in the perivitelline spaces and forty-six (56\%) were undergoing fertilization (Table 1). Of the forty-six ovarian eggs undergoing fertilization, three $(6.5 \%)$ had two polar bodies, three $(6.5 \%)$ had one polar body and forty $(87 \%)$ had no polar bodies. In all the ovarian eggs recovered $9 \mathrm{hr}$ after injection of HCG, regardless of whether or not their follicular cells were removed, the mean number of spermatozoa in a penetrated egg was remarkably hightwenty spermatozoa per egg.

When ovarian eggs were recovered $11 \mathrm{hr}$ after injection of HCG, the majority were still in the follicles, but seven of 161 eggs were recovered from the ovarian sacs or oviducts. Following insemination with epididymal spermatozoa, fifty-five $(34 \%)$ of the 161 eggs were undergoing fertilization and had normal first and second polar bodies.

\section{Fertilization of mouse eggs at various times after ovulation}

The eggs recovered from the oviducts of mice 13 to $15 \mathrm{hr}$ after injection of HGG were surrounded by compact cumulus oophorus. Those recovered $19 \mathrm{hr}$ after injection of HCG were in loose cumulus and some of these recovered $21 \mathrm{hr}$ after HCG injection were separated from the cumulus oophorus and the periviteline space was enlarged. The proportion of eggs undergoing fertilization and their condition following insemination in vitro at various times after ovulation are presented in Table 1. A relatively high proportion of eggs were penetrated (30 to $69 \%$ ) up to $23 \mathrm{hr}$ after the injection of HCG; i.e., about $10 \mathrm{hr}$ after ovulation. At $25 \mathrm{hr}$ after injection (about $12 \mathrm{hr}$ after ovulation), the perivitelline spaces had enlarged and very few eggs were penetrated $(14 \%)$. Of the 110 aged eggs recovered $27 \mathrm{hr}$ after injection of HCG, two (2\%) had a sperm tail on the vitellus, but no sperm head or male pronucleus could be found in the vitellus $8 \mathrm{hr}$ after insemination. Thirty-one hr after HCG injection, eggs with large 


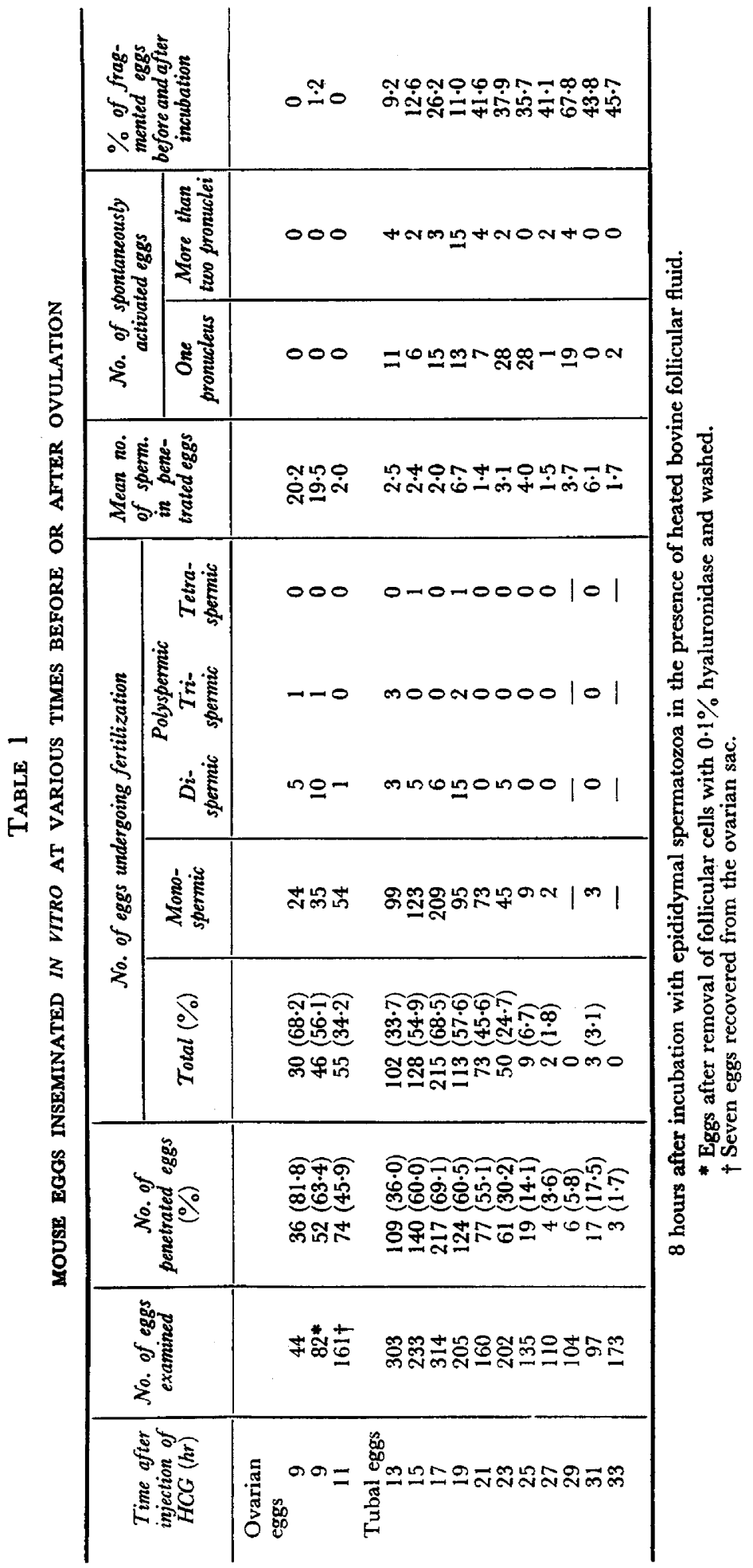


perivitelline spaces were found in the narrow posterior part of the ampulla; of the seventeen penetrated eggs, three contained morphologically abnormal sperm heads which were probably degenerating as they were not distinct in the vitellus.

From these observations, it appeared that, as in the case of fertilization in vivo (Marston \& Chang, 1964), the fertile life of mouse eggs lasted for 10 to $12 \mathrm{hr}$ after ovulation.

Following incubation, spontaneous activation was found in the tubal eggs but not in the ovarian eggs and the proportion of fragmented eggs after incubation appeared to be higher as the eggs aged (Table 1).

Insemination of eggs in vitro with epididymal spermatozoa from different strains of mice

Tubal eggs were recovered from the superovulated females of coloured C57BL/J6 strain, 15 to $21 \mathrm{hr}$ after injection of HGG, and inseminated with spermatozoa from the albino Swiss-Webster strain. The concentration of spermatozoa for insemination, the proportion of penetrated eggs and the condition of eggs are presented in Table 2 . The percentages of penetrated eggs were not low $(61 \%)$, but the number of spermatozoa in a penetrated egg $(6.2$ spermatozoa/egg) was higher compared with those eggs of the albino Swiss-Webster mouse inseminated with albino Swiss-Webster spermatozoa (three spermatozoa/ egg) (Tables 1 and 2).

Eggs recovered from the superovulated albino Swiss-Webster mice 15 to 16 $\mathrm{hr}$ after HCG injection were inseminated with spermatozoa from males of coloured YS/ChWf-dw strain. The proportion of penetrated eggs $(23 \%)$ and the number of spermatozoa (one spermatozoon/egg) in a penetrated egg was lower when compared with either Swiss-Webster eggs inseminated with SwissWebster spermatozoa (three spermatozoa/egg) or C57BL/J6 eggs inseminated with Swiss-Webster spermatozoa (six spermatozoa/egg). Judging from the results, sperm penetration appeared to be affected by spermatozoa or eggs of different strains of mice used for fertilization. The presence of fragmented eggs (Table 2) may be due to the large number of eggs obtained following superovulation.

\section{Effect of epididymal extract on sperm penetration}

Epididymal extract was added to the egg clot before the addition of bovine follicular fluid and sperm suspension. Of 178 eggs incubated with spermatozoa in the presence of epididymal extract at $1 / 3$ concentration, only $6 \%$ were penetrated, although 30 to $50 \%$ of the spermatozoa were still motile $8 \mathrm{hr}$ after incubation (Table 3). Of the motile spermatozoa, 50 to $70 \%$ reacted and had lost their acrosomes. At a 1/6 concentration of epididymal extract, about $30 \%$ of motile spermatozoa were also seen and the percentage of spermatozoa without their acrosomes at the end of the incubation period was about $74 \%$. However, penetration had only occurred in one of 120 eggs. The percentage of penetrated eggs ( 1 to $6 \%$ ) in the experimental group was lower than that in the control group (18\%). It appeared that the presence of epididymal extract in the preparation had inhibited sperm capacitation and sperm penetration under the experimental conditions. 


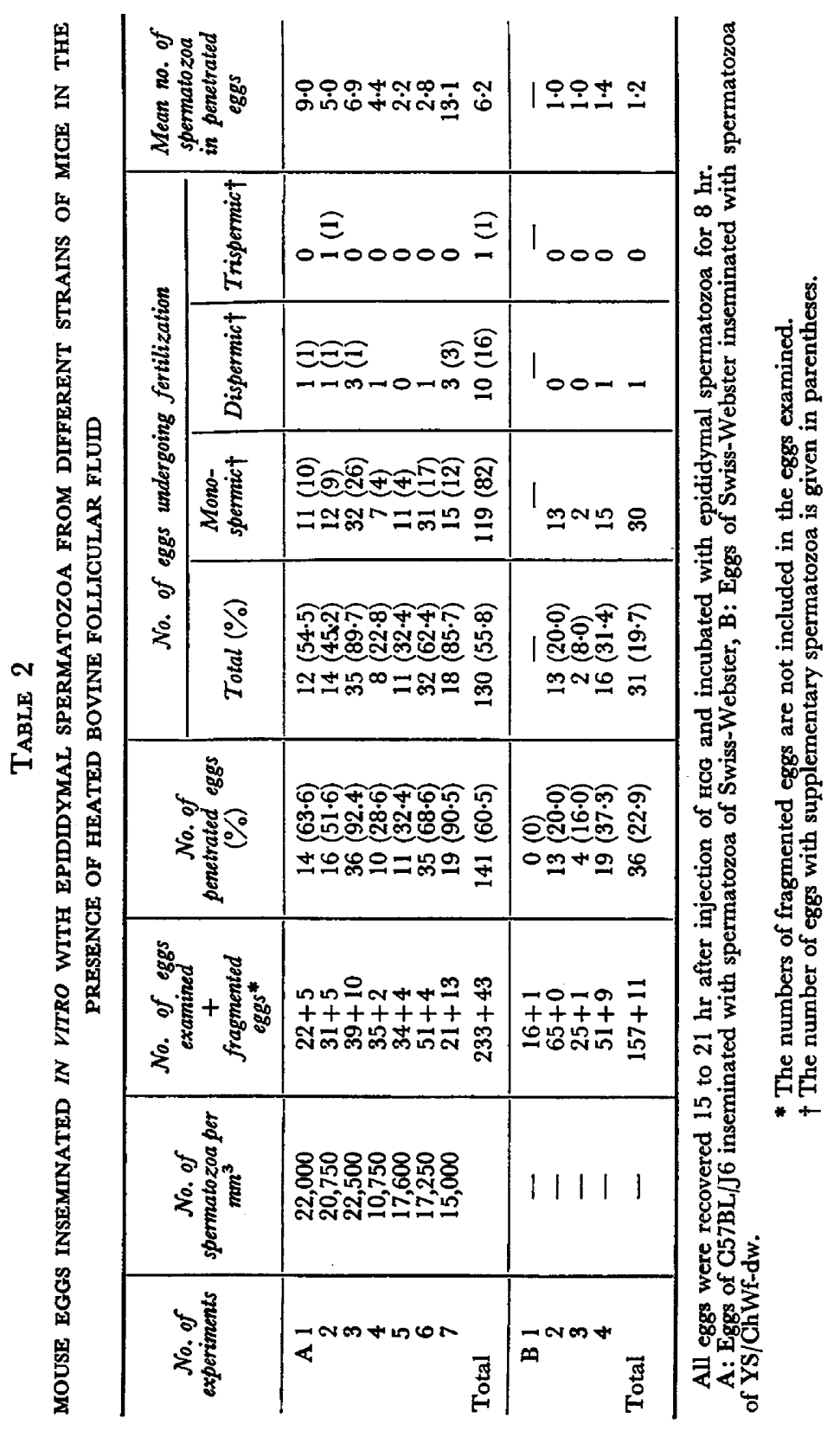



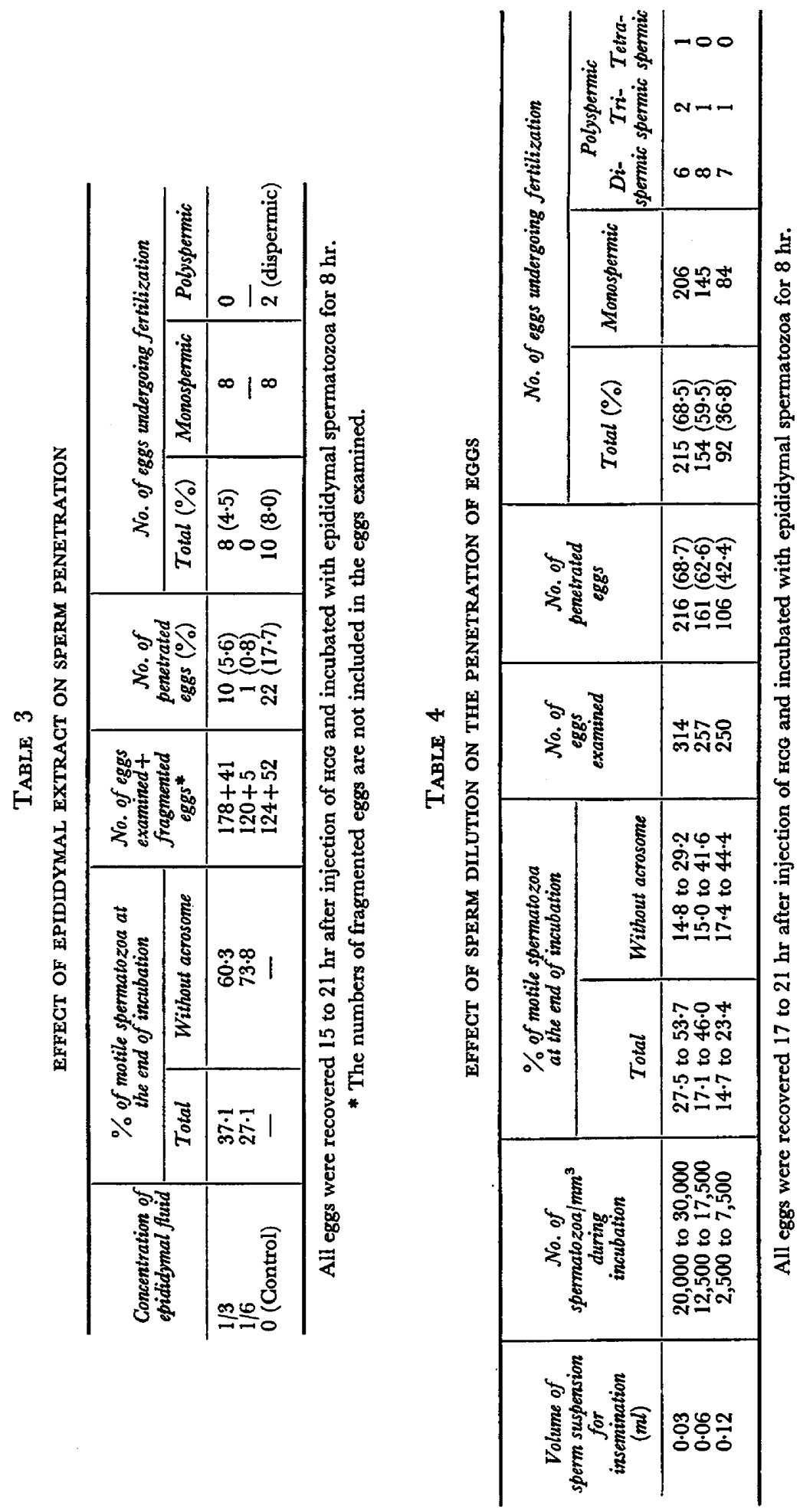

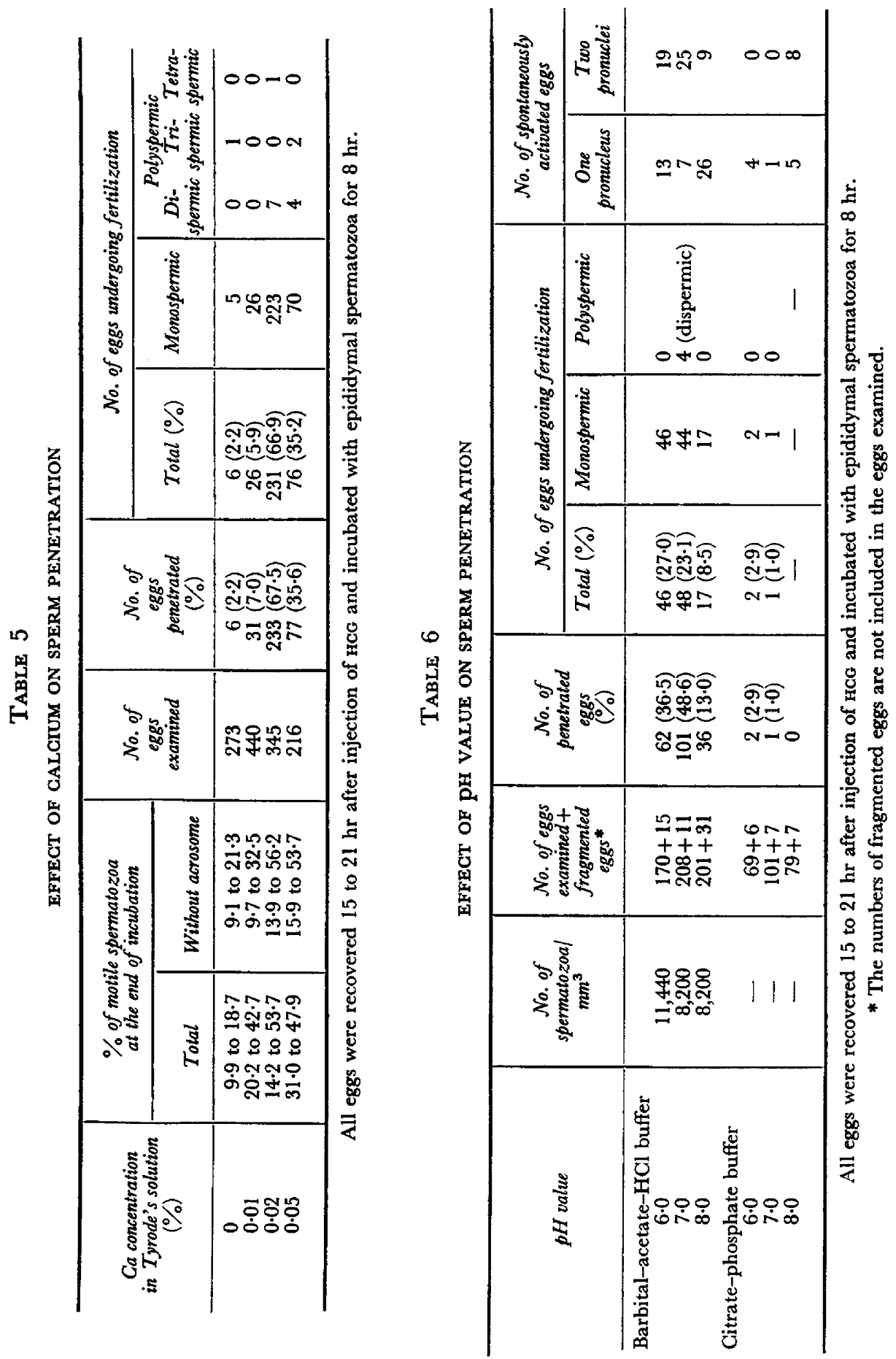
Effect of sperm dilution on the penetration of eggs in vitro

Approximately $0.01 \mathrm{ml}$ of epididymal sperm suspension in $0.03,0.06$ or $0.12 \mathrm{ml}$ of a mixture of one portion of heated bovine follicular fluid and three portions of Tyrode's solution was used for each group of eggs in a watch glass covered with oil. The total number of spermatozoa in each preparation during incubation was not very different but the concentration of spermatozoa in each preparation differed. The results of this study are presented in Table 4. It can be seen that the proportion of penetrated eggs did not differ for a final volume of 0.03 or $0.06 \mathrm{ml}$. In a final volume of $0.12 \mathrm{ml}$, the number of actively motile spermatozoa and the proportion of penetrated eggs appeared to decrease.

\section{Effect of calcium ions on sperm penetration}

When epididymal spermatozoa were incubated with eggs in Ca-free Tyrode's solution, the number of motile spermatozoa was decreased at the end of incubation. The proportion of total motile spermatozoa and that of motile spermatozoa without acrosomes at the end of incubation were high in the presence of calcium. The proportion of penetrated eggs was also high when the calcium concentration was $0.02 \%$, as in the case of Tyrode's solution. Higher concentrations of calcium ions $(0.05 \%)$ may have an inhibitory effect on sperm penetration (Table 5).

\section{Effect of $p H$ on sperm penetration}

When the insemination medium was buffered to a $\mathrm{pH}$ value of $6 \cdot 0,7.0$ or 8.0 with barbital-acetate- $\mathrm{HCl}$, the proportion of penetrated eggs was $37 \%$, $49 \%$ and $13 \%$, respectively (Table 6 ). In a medium with a high $\mathrm{pH}$ value, agglutination of spermatozoa with already scattered follicular cells occurred. Only a few motile spermatozoa were attached to the zona pellucida at the end of incubation. In a medium buffered with citrate-phosphate at a $\mathrm{pH}$ value of $6 \cdot 0,7 \cdot 0$ or 8.0 , the proportion of penetrated eggs was very low and only a few penetrated eggs were obtained at $\mathrm{pH} 6$ and 7 (Table 6). From these results, it seems that it is not necessarily the absolute $\mathrm{pH}$ value, but rather the components of the buffer solution which may affect the capacitation of mouse spermatozoa and the penetration of mouse eggs.

\section{DISGUSSION}

Rabbit eggs obtained before nuclear maturation from ovarian follicles can be fertilized and develop into young when transferred into the tubes of mated rabbits, but the probability of fertilization increased when oocytes were recovered 7 to $11 \mathrm{hr}$ after the injection of HCG, e.g. $3 \mathrm{hr}$ before ovulation, just before the first maturation division (Chang, 1955). Studies in vivo of mouse eggs have shown that the fertile life of mouse eggs after ovulation may last about $12 \mathrm{hr}$ (Long, 1912), $6 \mathrm{hr}$ (Lewis \& Wright, 1935), $8 \mathrm{hr}$ (Rumner \& Palm, 1953) or 15 hr (Marston \& Chang, 1964). The present study in vitro tended to confirm the reports that mouse eggs obtained from ovarian follicles can be penetrated $9 \mathrm{hr}$ after injection of HCG, about $4 \mathrm{hr}$ before ovulation and that their capacity to undergo fertilization after ovulation lasts for about 10 to $12 \mathrm{hr}$. 
The penetration of large numbers of spermatozoa through the zona pellucida and the high incidence of polyspermy are common features in the study of fertilization in vitro of hamster eggs (Yanagimachi \& Chang, 1964; Yanagimachi \& Noda, 1970) and mouse eggs (Iwamatsu \& Chang, 1969, 1970). The present study, however, revealed that the mean number of spermatozoa in a penetrated egg was much higher when mouse eggs obtained from follicles were at an early stage (twenty spermatozoa/egg) than at a later stage (two spermatozoa/egg) or after ovulation (1.4 to 6.7 spermatozoa/egg) (Table 1 ).

Eggs obtained from follicles and inseminated before nuclear maturation can be penetrated and undergo the early stage of fertilization. The failure of extrusion of the first and the second polar body was observed in large numbers of eggs, although the sperm head had enlarged or been transformed into a pronucleus. It is of interest to determine whether such fertilized eggs can develop and what will be their chromosomal complement.

When the aged eggs were exposed to spermatozoa, the number of spermatozoa in a penetrated egg was neither increased nor decreased (Table 1). It appears that the 'zona reaction' to block the further entry of spermatozoa (Braden, Austin \& David, 1954) develops shortly before ovulation and that this reaction persists during the fertile life of the mouse egg. In the hamster, however, this reaction was reported to be stronger soon after ovulation rather than before, or 2 to $3 \mathrm{hr}$ after, ovulation (Barros \& Austin, 1967). Besides the zona reaction in the mouse eggs, the existence of a block mechanism in the vitelline membrane of mouse eggs has been shown in a previous study (Iwamatsu \& Chang, 1970). The development of this vitelline block, however, was not obvious in the ovarian eggs because the number of polyspermic eggs was not higher in the early ovarian eggs than in the tubal eggs (Table I).

In the aged tubal eggs inseminated 25 to $33 \mathrm{hr}$ after ovulation (Table 1), only a few eggs were penetrated and the disappearance or obscurity of the sperm head in the vitellus, leaving a sperm tail in the perivitelline space, was observed on many occasions. Even when the sperm head was found in the vitellus, its transformation into pronucleus and activation of the eggs failed. These observations may indicate the disappearance of certain reactive substances to sperm nucleus in the vitellus when the eggs age. The existence of such a substance in the germinal vesicle of fish eggs has been suggested (Iwamatsu, 1965, 1966) and the presence of a substance required for the initiation of DNA synthesis in the nuclei of frog eggs has also been demonstrated (Graham, Arms \& Gurdon, 1966; Gurdon, 1967). The presence of a similar substance in mouse eggs is still to be determined.

The possibility of obtaining a high rate of fertilization by inseminating eggs in vitro with spermatozoa of a different strain was reported by Whittingham (1968). In the present study, it was shown that when eggs of Swiss-Webster (Table 1) and C57BL/J6 (Table 2) mice were inseminated with spermatozoa of Swiss-Webster, the proportion of eggs undergoing fertilization (56 to $69 \%$ ) was much higher than when eggs of Swiss-Webster mice were inseminated with spermatozoa of YS/ChWf-dw mice $(20 \%$, Table 2). Since the fertile life of eggs and the fertilizing life of spermatozoa may vary according to strain, and since the environmental conditions required for sperm capacitation and egg 
penetration are so delicate, variations in the capacity of the eggs of one strain to be fertilized by the spermatozoa of another are to be expected under certain experimental conditions.

When a small volume of solution was used to obtain epididymal spermatozoa and a relatively low concentration of spermatozoa (8,000 to 14,000 spermatozoa/ $\mathrm{mm}^{3}$ ) was used for insemination, the proportion of penetrated eggs was only $37 \%$ (Iwamatsu \& Chang, 1969). In the present study, the sperm concentration was high $\left(20,000\right.$ to $\left.30,000 / \mathrm{mm}^{3}\right)$ and the proportion of penetrated eggs was also high $(69 \%)$. It was thought that either the sperm concentration or some components of epididymal fluid might affect sperm penetration. It appeared that epididymal extract might have inhibited sperm penetration although it had no effect on acrosome reaction (Table 3 ) and a high concentration of spermatozoa in a small volume did facilitate sperm penetration (Table 4 ).

Calcium ions appear to play an important rôle in fertilization in lower organisms (Yamamoto, 1939, 1954; Dettlaf, 1958; Dan, 1967). In the present study, the importance of calcium ions in fertilization of mouse eggs in vitro was also shown (Table 5). In a medium with a low concentration $(0.01 \%)$, the acrosome reaction seemed to occur in only a small proportion of spermatozoa and they retained their motility for a short time; thus the proportion of penetrated eggs was low $(7 \%)$. In a medium of high calcium concentration $(0.05 \%)$, there is a possibility that the spermatozoa which have lost their acrosomes may have been hindered in passing through the zona pellucida, and the proportion of penetrated eggs $(36 \%)$ was lower than in a medium of $0.02 \%$ calcium, the normal concentration present in Tyrode's solution (Table 5).

A relatively high proportion of eggs have been fertilized in vitro in solutions of high $\mathrm{pH}$ value-rabbit eggs at $\mathrm{pH} 7.6$ to 8.2 (Suzuki \& Mastroianni, 1965) and hamster eggs at $\mathrm{pH} 7.6$ (Bavister, 1969). We have found, however, that the proportion of penetrated eggs was higher at a pH of 6 or $7(37$ to $49 \%)$ than at a $\mathrm{pH}$ of $8(13 \%)$ when barbital-acetate- $\mathrm{HCl}$ buffer was used, while only a few eggs were penetrated at a $\mathrm{pH}$ of 6 or 7 and none at a $\mathrm{pH}$ of 8 when citratephosphate buffer was used (Table 6). Since free calcium decreases significantly with increase of $\mathrm{pH}$ in serum (Toribara, Terepka \& Dewey, 1957) and increased dissociation of calcium from serum protein can be induced by a decrease of $\mathrm{pH}$ value (Loken, Havel, Gordon \& Whittington, 1960), it is possible that such reactions may have occurred in our medium which contained bovine follicular fluids. The low proportion of penetrated eggs at a high $\mathrm{pH}$ in the present study may have been influenced by the concentration of free calcium in the medium or by the high concentration of binding calcium on the surface of spermatozoa which may cause their agglutination. Various interrelated factors appear to be involved in the maintenance of the physiological activities of the spermatozoa as well as of the ova and also affect sperm penetration. A complete isolation of the many interacting factors can hardly be expected under our experimental conditions.

\section{ACKNOWLEDGMENT}

This work was supported by a grant (HD 03003) from the USPHS and a grant 
from the Ford Foundation. M.C.C. held a Research Career Award of the NICHD (K6-HD-18,334). Thanks are due to Mrs Rose Bartke for assistance.

\section{REFERENCES}

Barros, G. \& Austin, G. R. (1967) In vitro fertilization and sperm acrosome reaction in the hamster. F. exp. Zool. 166, 317.

Bavister, B. D. (1969) Fertilization of mammalian eggs in vitro. Res. Reprod. 1, 1.

Braden, W. H., Austin, C. R. \& David, H. A. (1954) The reaction of the zona pellucida to sperm penetration. Aust. 7. biol. Sci. 7, 391.

Brinster, R. L. \& Biggers, J. D. (1965) In vitro fertilization of mouse ova within the explanted Fallopian tube. 7. Reprod. Fert. 10, 277.

Chang, M. C. (1955) Fertilization and normal development of follicular oocytes in the rabbit. Science, N.Y. $121,867$.

DAN, J. C. (1967) Acrosomal reaction and lysins. In: Fertilization, p. 237. Eds. G. B. Metz and A. Monroy. Academic Press, New York.

DetTLAF, T. A. (1958) The role of calcium ions for the stimulation of eggs and spread of cortical reaction in Acipenseridae. Dokl. Acad. Nauk SSSR (Russian), 121, 944.

Edwards, R. G. \& Gates, A. H. (1959) Timing of the stages of the maturation divisons, ovulation, fertilization and the first cleavage of eggs of adult mice treated with gonadotrophins. F. Endocr. 18, 292.

Graham, C. F., Arms, K. \& Gurdon, J. B. (1966) The induction of DNA synthesis by frog egg cytoplasm. Devl Biol. 14, 349.

GURdon, J. B. (1967) On the origin and persistence of a cytoplasmic state inducing nuclear DNA synthesis in frogs' eggs. Proc. natn. Acad. Sci. U.S.A. 58, 545.

Iwamatsu, T. (1965) Reaction of germinal vesicle material to the penetrating spermatozoon (In Japanese). Zool. Mag., Tokyo, 74, 339.

Iwamatsu, T. (1966) Role of germinal vesicle materials on the acquisition of developmental capacity of the fish oocyte. Embryologia, 9, 205.

Inamatsu, T. \& Ghang, M. C. (1969) In vitro fertilization of mouse eggs in the presence of bovine follicular fluid. Nature, Lond. 224, 919.

Inamatsu, T. \& Chang, M. C. (1970) Further investigation of capacitation of sperm and fertilization of mouse eggs in vitro. . exp. Zool. 175, 271.

LEWIs, W. H. \& WRIGHT, E. S. (1935) On the early development of the mouse egg. Contr. Embryol. 25, 113.

Loken, H. F., HAVEL, R. J., Gordon, G. S. \& Whittington, S. L. (1960) Ultracentrifugal analysis of protein-bound and free calcium in human serum. F. biol. Chem. 235, 3654.

LoNG, J. A. (1912) The living eggs of rats and mice with a description of apparatus for obtaining and observing them. Univ. Calif. Publs Zool. 9, 105.

McGaughey, R. W., Marston, J. H. \& Chang, M. C. (1968) Fertilizing life of mouse spermatozoa in the female tract. F. Reprod. Fert. 16, 147

Marston, J. H. \& Chang, M. G. (1964) The fertilizable life of ova and their morphology following delayed insemination in mature and immature mice. F. exp. Zool. 155, 237.

Pavlok, A. (1967) Development of mouse ova in explanted oviducts: fertilization, cultivation, and transplantation. Science, N.Y. 151, 1457.

Rumner, M. N. \& Palm, J. (1953) Transplantation and survival of unfertilized ova of the mouse in relation to post-ovulatory age. F. exp. Zool. 124, 303.

Suzuki, S. \& Mastroianni, L. (1965) In vitro fertilization of rabbit ova in tubal fluid. Am. F. Obstet. Gynec. 93, 465.

Toribara, T. Y., Terepka, A. R. \& Dewey, P. A. (1957) The ultrafiltrable calcium of human serum. I. Ultrafiltration methods and normal values. $\mathcal{F}$. clin. Invest. 36, 738 .

Whittingham, D. G. (1968) Fertilization of mouse eggs in vitro. Nature, Lond. 220, 592.

Yamamoto, T. (1939) Cortical layer of the egg of Oryzias latipes at the time of fertilization. Proc. imp. Acad. Japan, 15, 269.

Yамамото, T. (1954) Physiological studies on fertilization and activation of fish eggs. V. The role of calcium ions in activation of Oryzias eggs. Expl Cell Res. 6, 56.

YANAGIMACHI, R. (1969) In vitro acrosome reaction and capacitation of golden hamster spermatozoa by bovine follicular fluid and its fractions. J. exp. Zool. 170, 269.

YANAGIMACHI, R. \& GHANG, M. C. (1964) In vitro fertilization of golden hamster ova. F. exp. Zool. 156, 361 .

YANagimachi, R. \& NodA, Y. (1970) Physiological changes in the postnuclear cap region of mammalian spermatozoa: a necessary preliminary to membrane fusion between sperm and egg cells. $\mathcal{F}$. Ultrastruct. Res. 31, 486. 